Original Research Paper

\title{
Lithofacies and Depositional Environment from Geophysical Logs of EMK Field, Deepwater Niger Delta, Nigeria
}

\author{
${ }^{1}$ Emeka A. Nwagwu, ${ }^{2}$ Godwin O. Emujakporue, ${ }^{1}$ Sylvester A. Ugwu and ${ }^{1}$ R. Oghonya \\ ${ }^{1}$ Department of Geology, University of Port Harcourt, Nigeria \\ ${ }^{2}$ Department of Physics, University of Port Harcourt, Nigeria
}

\author{
Article history \\ Received: $10-02-2018$ \\ Revised: 03-08-2018 \\ Accepted: 03-12-2019 \\ Corresponding Author: \\ Godwin O. Emujakporue \\ Department of Physics, \\ University of Port Harcourt, \\ Nigeria \\ Email: owin2009@yahoo.com
}

\begin{abstract}
The lithofacies and environments of deposition of the EMK field, in parts of the deepwater zone of Niger Delta Basin, have been carried out. Geophysical well logs from two deep oil wells were used. Shale and sand were identified in the gamma ray logs. The shale lithology is more dominant than the sand and this was interpreted as the marine Akata Formation. Four sand bodies were identified and correlated across the wells. The shapes of the gamma ray signatures are funnel, bell and cylindrical. Prograding, retrograding and aggradational parasequences were identified from the stacking patterns of the gamma ray curves. The environments of deposition delineated for the study area are slope fans and basin floor fans.
\end{abstract}

Keywords: Deepwater, Niger Delta, Gamma Ray Log, Lithofacies, Gamma Ray Curves, Depositional Environments

\section{Introduction}

The study area EMK field is part of the deepwater depositional belt in the Niger Delta, which extends from isobaths contour of 2000 to $4000 \mathrm{~m}$. The area is about $120 \mathrm{~km}$ off the coast of the western Niger Delta region and within the fold-thrust province in the continental slope and abyssal plain (Corredor et al., 2005). This area is one of the most important exploration provinces in the world and most of the deepwater hydrocarbon reservoirs are discovered within the Turbidites (Vail, 1987; Weimer and Pettinghill, 2007). It has been discovered that quality reservoir sand bodies are deposited on both the continental slope and basin floor.

Turbidity currents, sediment supply, tectonism and changes in sea-level are the main controls in deep water depositional system (Mutti and Normark, 1991; Readings and Richards, 1994; Adeogba et al., 2005). Turbidite deposits are graded and usually show a fining upward sequence (Bouma, 1962; Bouma et al., 1985; Lowe, 1982).

Different physical, chemical and biological processes act to transport and deposit sediment in any given depositional environment. These processes are responsible for the distributions of grain size and sedimentary structures that characterize deposited sediment. Relating these features to the processes that produced them is the basic method used by geoscientists for interpreting the depositional environment of the sedimentary basin.
The internal facies of submarine fans formed at the base of slopes vary from channelized sand and gravel bodies to sheet-like, thin, graded beds deposited by turbidity currents in distal parts of the fan. An upward fining wireline motif is usually associated with a vertical sequence through channelized portions of the fan. An interdigitate and irregular wireline motif is usually associated with a vertical sequence through the more distal parts of the fan, which is an indication of an alternation between sandstone and mudstone beds.

The description and interpretation of the core and wireline $\log$ of clastic reservoir is the foundation of lithofacies analysis (Siemers and Tillman, 1981). Most times, core samples are not available for the analysis, thereby leading to the sole dependency on wireline logs. Lithofacies is the fundamental units for the analysis and interpretation of the environment of deposition. Interpretation of the environment in which lithofacies were deposited from analysis of cored sequences and wireline logs involves relating the identified lithofacies to the physical and biological processes that produced them.

Usually, shaliness is an indication of the intensity of gamma rays produced by radioactive elements in rock bodies. Every shale has a distinct radioactive source that may be used to distinguish shale and sandstone, shale and limestone and finally shale and evaporate. The fluctuation observed in the gamma ray $\log$ indicates the change in mineralogy in rocks. A 
radioactive element is associated with varying composition in rocks and the amount and types depend on the depositional environment.

Geophysical well logs are commonly used for well correlation, lithology identification and formation evaluation. Currently, well log (gamma ray) shapes are being applied in facies analysis and determination of the depositional environment. The shape of Spontaneous Potential (SP) and gamma ray logs is used for classifying sand bodies. The gamma ray log is the most widely used $\log$ for facies and sequence stratigraphy analysis because it shows a different variety of shapes, greater definition and also has more character (Dalrymple and Choi, 2007). Many researchers have applied log shapes for facies analysis. The variation in gamma ray log character may be interpreted in terms of grain size and an abrupt change in gamma ray log response is interpreted to be related to sharp lithological breaks associated with unconformities and sequence boundaries. The objectives of this study are to evaluate the facies and depositional environment of the deepwater Niger Delta The basic gamma ray log shapes used for interpreting the depositional environment are funnel, bell and cylinder. The major depositional environment in the deep water is the slope and basin floor. Deepwater hydrocarbon reservoirs can be structural or/and stratigraphy. Knowledge of the geometry, architecture, facies and reservoir quality is crucial for the exploration and exploitation of hydrocarbon in this environment.

\section{Geology of the Study Area}

The study area is located in the western deepwater zone of the Niger Delta Sedimentary Basin and it extends from isobaths contour of 2000 to $4000 \mathrm{~m}$ (Fig. 1). The area is about $120 \mathrm{~km}$ off the coast of the western Niger Delta region and within the fold-thrust province in the continental slope and abyssal plain (Corredor et al., 2005). The offshore depobelt of the Niger Delta is a passive margin similar to the Gulf of Mexico (Dalrymple and Choi, 2007; Emujakporue, 2017). The Niger Delta starts development from the Cretaceous to Quaternary.

The stratigraphy of the Niger Delta is divided into three diachronous units of Eocene to Recent age that forms a major regressive cycle. These stratigraphy namely from the oldest to the youngest are the Akata, Agbada and Benin Formations (Short and Stauble, 1967; Doust and Omatsola, 1990; Amajor, 1986) as shown in Fig. 2. The Niger Delta is on the $3^{\text {rd }}$ cycle depositional sequence in the geology of Nigeria and it is deposited in a wedge-shaped basin (Covault and GRaham, 2008). The Akata Formation consists of pro-delta shales and clays with some turbidites sand bodies and it is of Paleocene to Recent. The approximate thickness of the Akata Formation is between 600 to $7000 \mathrm{~m}$. The Agbada Formation is Eocene to recent in age and consist of paralic sequences of sand and shales. The Agbada Formation has an approximate thickness of 300 to 4500 $\mathrm{m}$. The Benin Formation is of Miocene to recent in age and consist of continental sands and gravels and thickness $0 \mathrm{~m}$ to $2000 \mathrm{~m}$. The Benin Formation is an overburden layer in the Niger Delta and it is not deformed and there is the absence of faulting and folding (Doust and Omatsola, 1990). Researches by some previous geologists (Doust and Omatsola, 1990; Evamy et al., 1978; Avbovbo, 1978) in the basin has shown that it is dominated by simple rollover structure (folding/faulting), Structure with multiple growth faults and Graben (collapsed crest) structure.

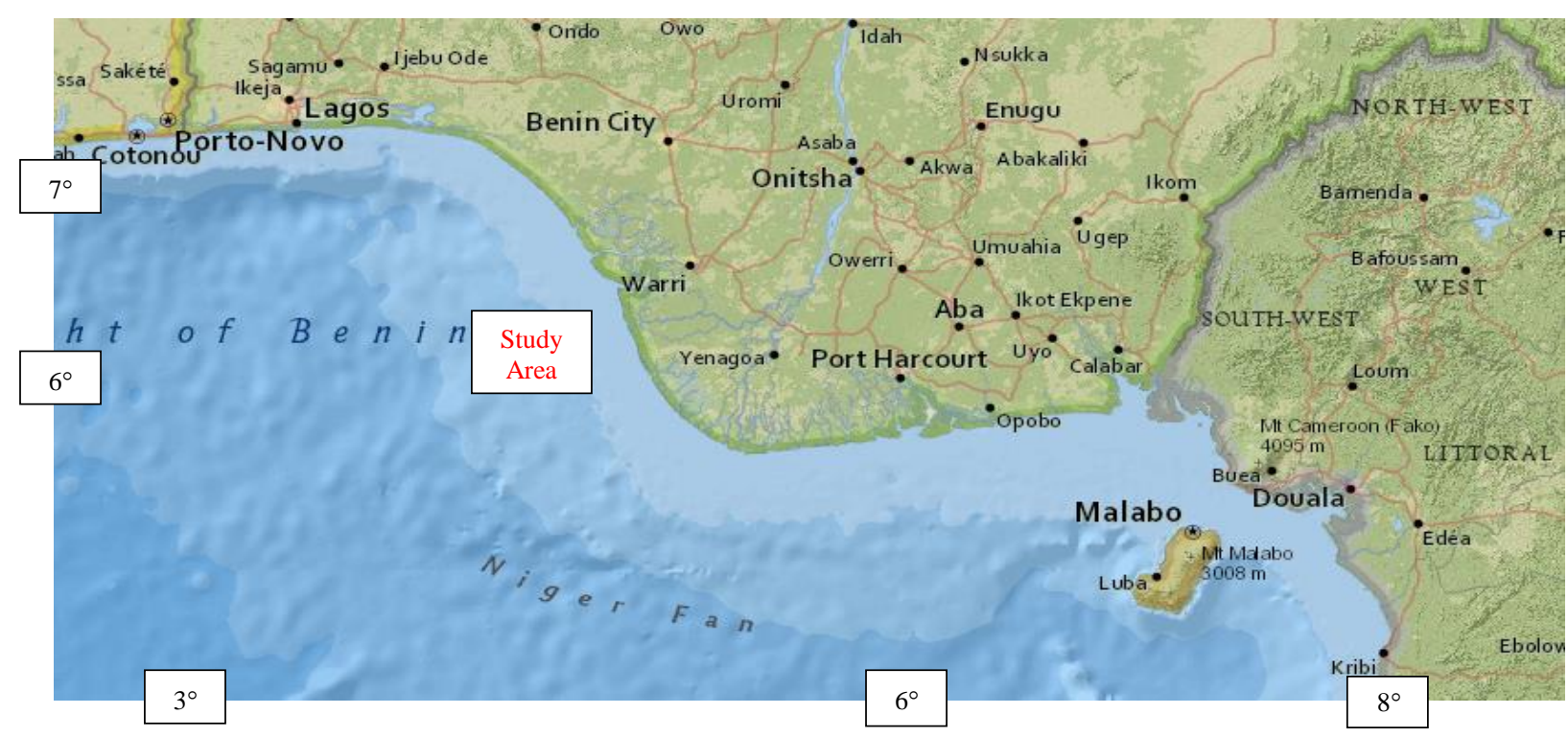

Fig. 1: Map of Niger Delta showing the location of the study area 


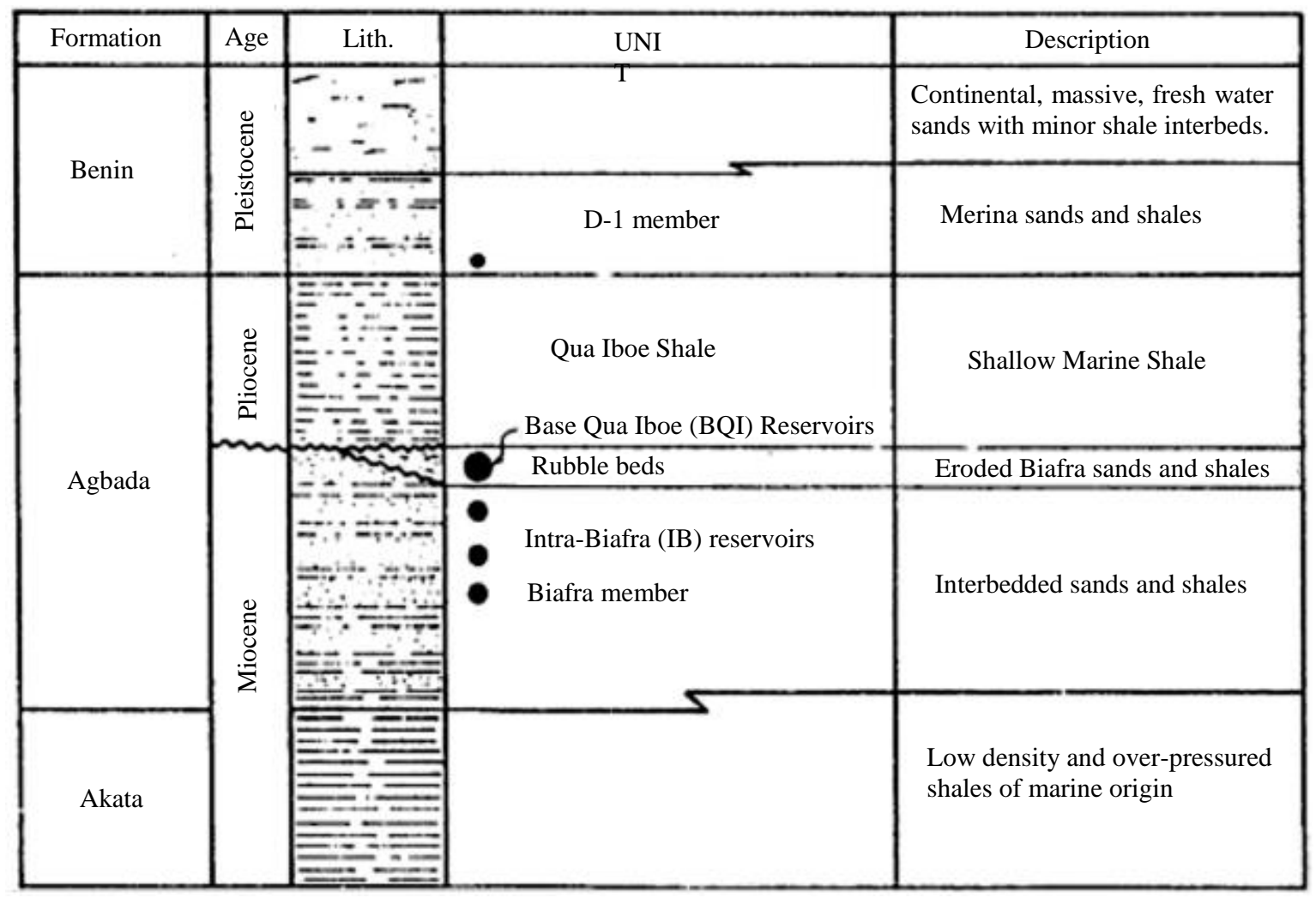

Fig. 2: Schematic diagram of the regional Stratigraphy of the Niger Delta. (Modified from (Doust and Omatsola, 1990; Corredor et al., 2005))

\section{Materials and Methods}

Composite geophysical logs from two deep oil wellsEMK-1 and EMK-2 were used for this study. The data were obtained from Nigerian Agip Exploration Limited (NAEL). The composite logs consist of gamma ray, resistivity, density, neutron and sonic. Schlumberger's Petrel 2010 version software was used for processing the data. The well coordinates were used to convert the log data into true vertical depth subsea (TVDSS). The two wells EMK-1 and EMK-2 were drilled to about $3335.2 \mathrm{~m}$ and $4971.77 \mathrm{~m}$ subsea depths respectively. The two wells logs were placed against each other to facilitate correlation and assessment of data quality. The following techniques were adopted for the data analysis:

\section{Lithology Identification}

The gamma ray logs were used for lithology identification. Gamma ray log records the radioactivity of the formation encountered in the boreholes. Shale lithology is usually associated with high gamma ray radioactive response while sandstone lithology is associated with low gamma ray value. The gamma ray $\log$ is also used as measures for grain size and subsequently for inferring depositional energy. Thus coarse-grain sand, which contains little mud, will have low gamma ray value, while a fine mud will have a high gamma ray value.

\section{Well Log Facies Identification}

The shape of gamma ray log signatures is a basic tool for the interpretation of lithofacies and depositional environments. Three types of gamma ray trends or shapes can be recognized when examining the log curves. Sharp breaks in the gamma ray curve are an indication of rapid change in energy distribution and it is used to identify sand and shale units. Abrupt changes in the gamma ray log response are interpreted to be related to sharp breaks associated with unconformities and sequence boundaries. The basic gamma ray log shapes are shown in Fig. 3 and they are as follows:

Funnel shape: This is a cleaning up trend and it represents a gradual upward decrease in gamma response. It is known as the prograding process and in deepwater settings, this shape indicates an increase in sand contents. This shape also represents a gradual change from clastic to carbonate deposition. It may be interpreted as a submarine fan lobe. 


\begin{tabular}{|c|c|c|c|c|}
\hline Shape & Smooth & Environments & Serrated & Environments \\
\hline $\begin{array}{l}\text { Cylindrical } \\
\text { Represents } \\
\text { uniform } \\
\text { distribution }\end{array}$ & & $\begin{array}{l}\text { Aeolian dunes } \\
\text { Tidal sands } \\
\text { Fluvial channels }\end{array}$ & & $\begin{array}{l}\text { Deltaic distributaries } \\
\text { Turbidites channels } \\
\text { Proximal deep-sea fans }\end{array}$ \\
\hline $\begin{array}{l}\text { Bell shape } \\
\text { Fining } \\
\text { upwards } \\
\text { sequences }\end{array}$ & & $\begin{array}{l}\text { Tidal sands } \\
\text { Alluvial sands } \\
\text { Braided streams } \\
\text { Fluvial channels } \\
\text { Point bars }\end{array}$ & & $\begin{array}{l}\text { Lacustrine sands } \\
\text { Deltaic } \\
\text { distributaries } \\
\text { Turbidites channels } \\
\text { Proximal deep-sea } \\
\text { fans }\end{array}$ \\
\hline $\begin{array}{l}\text { Funnel shape } \\
\text { Coarsing } \\
\text { upward }\end{array}$ & & $\begin{array}{l}\text { Barrier bars } \\
\text { Beaches } \\
\text { Crevasse splays }\end{array}$ & & $\begin{array}{l}\text { Distributary mouth } \\
\text { bars } \\
\text { Delta marine fringe } \\
\text { Distal deep-sea fans }\end{array}$ \\
\hline
\end{tabular}

Fig. 3: Gamma ray log signatures and depositional environment

Bell shape: This is a dirtying up trend and it is a gradual upward increase in gamma ray response. It is known as a retrograding process. This type of curve may reflect upward fining which is an indication of a lithology change from sand to shale. This trend is an indication of a decrease in depositional energy. In the deepwater environment, this curve reflects the waning of submarine fans and submarine channel that is reducing of sand content.

Cylindrical or Block shape: This type of trend is associated with low gamma ray value having sharp boundaries and no internal change. It is also known as an aggrading process. This type of curve is common in fluvial channel sands, turbidites and in a submarine canyon filled.

Symmetrical trend: This type of trend is associated with a gradual decrease and then a gradual increase in gamma values. It is an indication of a progradation, retrogradation of clastic sediments and a submarine fan.

A change in the energy of deposition is also an indication in the environment of deposition. Stability in the gamma ray curve is a result of little or no variation in the depositional environment. The characteristics of the gamma ray curve are also very important. The gamma ray may be smooth, serrated or complex. The nature of the upper and lower contacts of the curves is also very important in the interpretation.

\section{Determination of Well Log Stacking Patterns and Parasequences for Deepwater Environments}

The log curve shapes, morphology and the nature of the lower and upper boundaries with adjacent shale units are used to recognize the log motifs. The Gamma ray logs motifs in the deepwater setting are used to differentiate slope fans and basin floor fans. The stacking patterns of the gamma ray logs were used to characterize the rate of deposition and parasequences. The identified $\log$ motifs were used to describe the parasequence as either progradational, retrogradation or aggradational. A retrogradation stacking pattern is associated with a fining upward trend in the gamma ray log. A coarsing upward trend in the gamma ray curve means a progradational stacking pattern while a blocky trend in the gamma ray curve represents an aggradational stacking pattern. Forms of stacking patterns are:

Nervous and interbedded shape - log response is characterized by the stacking of increasing and decreasing thickness with interbedded channelized patterns. This form of stacking pattern showed either prograding, retrograding or aggrading features within the sand body. This type of gamma ray response is interpreted as a slope fan depositional system. 
Blocky and serrated shape - log response showed a cylindrical shape feature, but without abrupt terminations and facies dipping seaward. The facies showed either prograding, retrograding or aggrading features within the sand body. This can be interpreted as contourite facies in the basin floor fan depositional system.

Cylindrical or Blocky shape - the log response showed generally cylindrical or blocky morphology with quite abrupt upper and lower limits that are an indication of an abrupt decrease in gamma ray values. The facies showed aggrading features within the sand body and it is interpreted as basin floor fan depositional system.

\section{Results and Discussion}

The gamma ray log was used for the identification of lithology encountered in the wells. The log motifs of prograding, retrograding and aggrading features were identified in the study area and used to characterize the depositional environment. The depositional environments were recognized by vertical grain size, log shapes and morphology.

\section{Identified Lithology}

The gamma ray logs for both wells showed dominant shales (in black) and a streak of sand bodies (in yellow) as shown in Fig. 4. Sand bodies A, B, C and $\mathrm{D}$ were identified and correlated in wells EMK-1 and EMK-2. In the stratigraphy of the Niger Delta, this alternation of shale and sand bodies fall within the Akata formation which is of marine origin with dominant shales and probably turbiditic sand associated with minor amounts of clay and silt (Doust and Omatsola, 1990; Amajor, 1986; Burke, 1972). The thicknesses of the reservoirs in EMK-1 are greater than those in EMK-2. The blackish shales are massive and amalgamated in well EMK-1 whilst it is massive and amalgamated up to the top of sand body B in well EMK-2 and become more distal and less laterally thick from bottom of sand body $\mathrm{B}$, basinward.

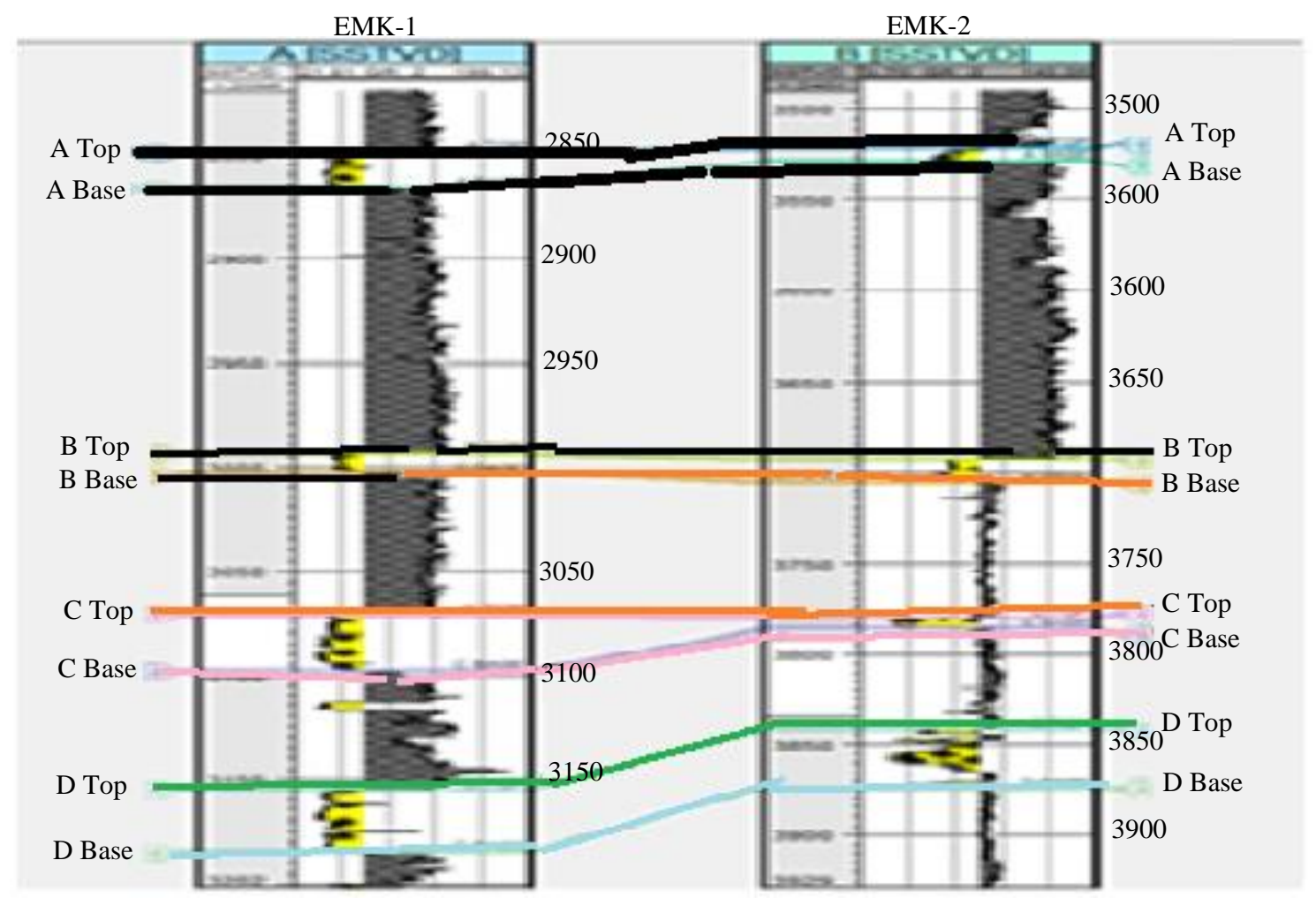

\section{LEGEND}

\section{Sandbody}

Shale

Fig. 4: Tops and bottoms surfaces (A, B, C and D) of sand body features in wells EMK-1 and EMK-2 


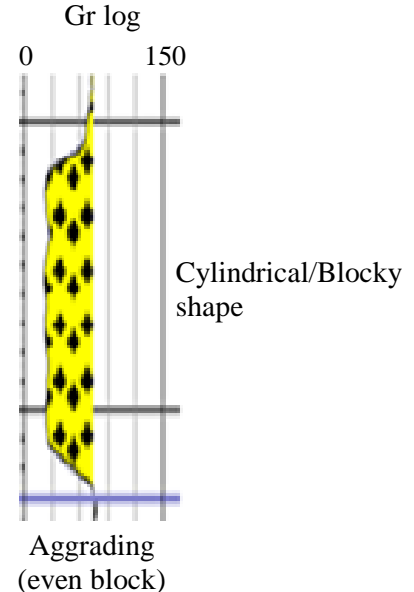

(a)

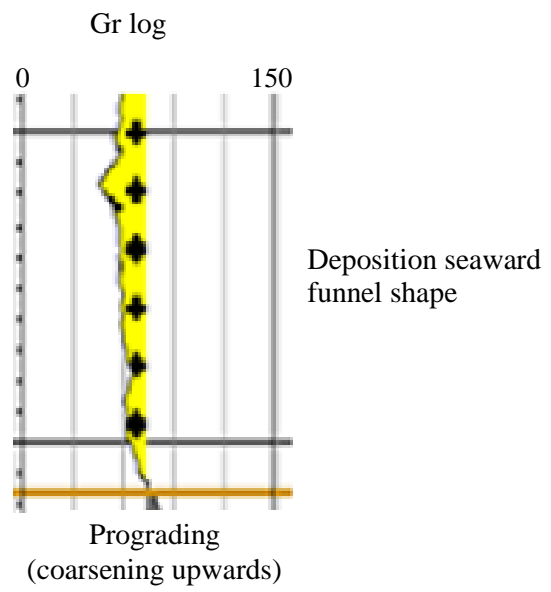

(b)
Gr $\log$

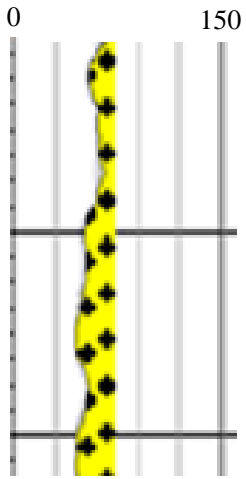

Deposition landward bell shape

Retrograding (fining upwards)

(c)

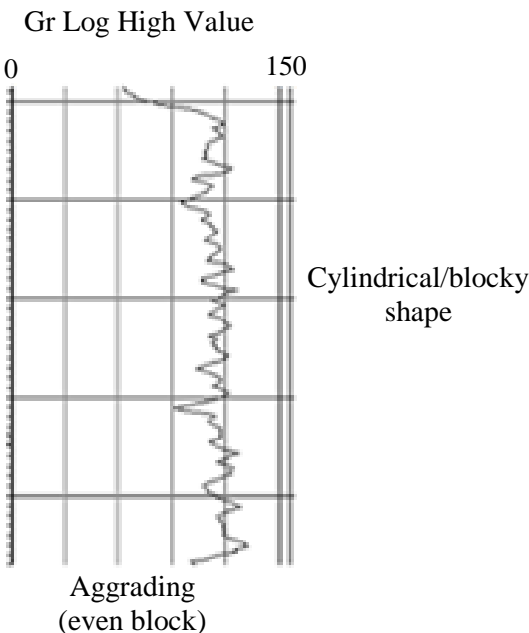

(d)

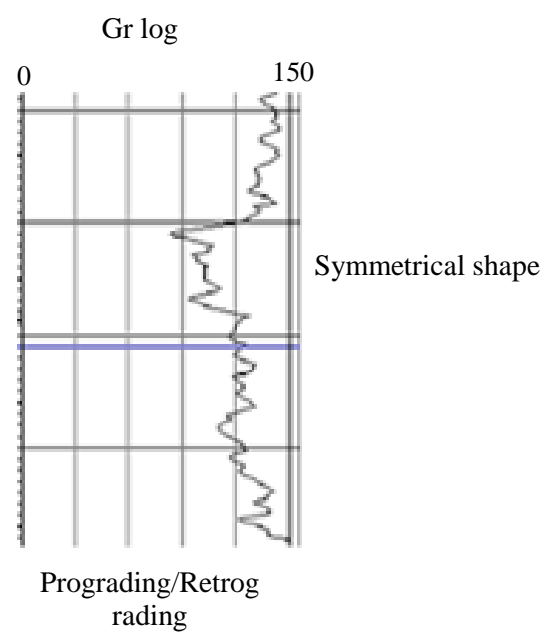

(e)

Fig. 5: Gamma ray log signatures observed within Akata Formation in EMK Field

\section{Identified Gamma Ray Facies}

The various curves identified in the gamma ray logs from the study area are shown in Fig. 5. The curves identified are funnel, bell, cylindrical and symmetrical. These various curves and the stacking patterns are an indication that the deepwater has been subjected to progradation, aggradation and retrograding. Serrated blocky or cylindrical curve shape without abrupt termination dominates the gamma ray logs.

\section{Gamma Ray Stacking Patterns and Parasequences}

Table 1 shows the various stacking patterns and parasequences identified in the study area. Both nervous and interbedded shape log response, blocky and serrated shape and cylindrical shapes were observed in the gamma ray logs. The pattern of deposition from bottom to top was identified and therefore bottom-top method was applied to interpret the turbidite sequences. Some sequences, for example, were shaly sand to sand (coarsening upwards sequence); clay, shaly sand to sand (coarsening upwards sequence); sand, shaly sand to clay (fining upwards sequence). This is also a confirmation that the area is characterized by prograding, retrograding and aggrading parasequences within the sand bodies.

\section{Depositional Environments}

The gamma ray log is often used to determine the shale content of a formation. The shaliness of a formation does not change suddenly rather it takes place 
gradually with depth. The gradual changes are a function of the litho-facies and the environment of deposition of the rock and they are associated with changes in grain size and sorting. The changes in grain size and sorting are usually controlled by facies and depositional environments.

Table 1: Gamma ray motifs used to characterize the depositional systems in the study area (modified from Rider, 2002)
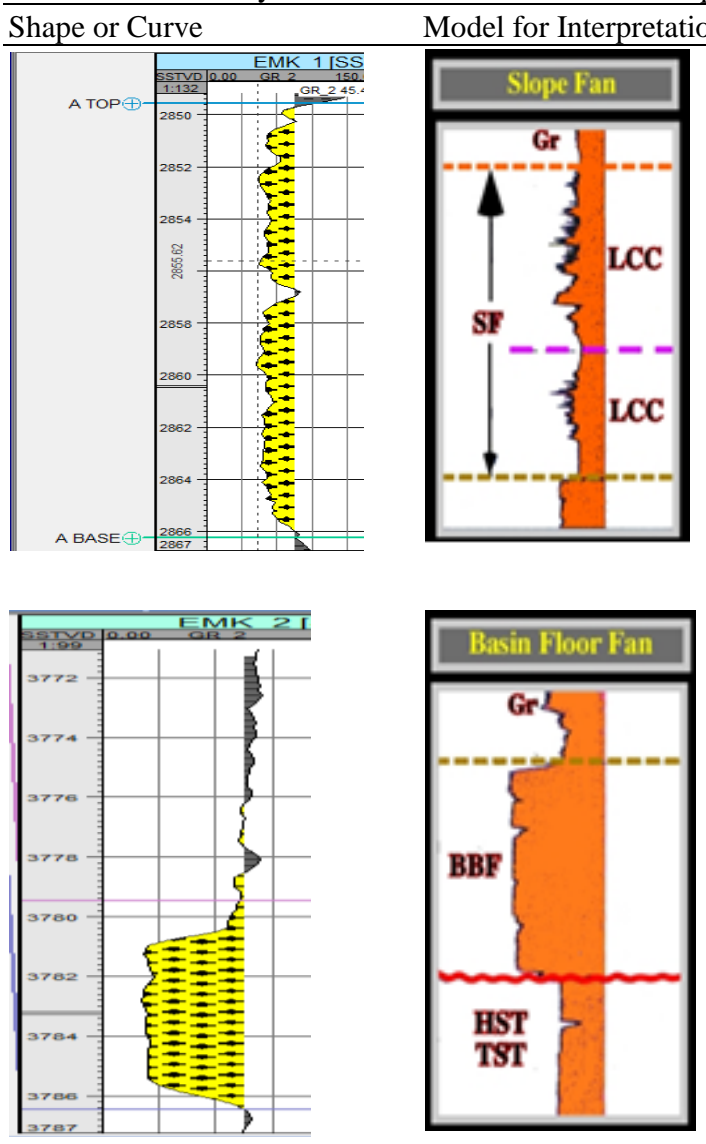

Cylindrical or Blocky shape - the log response showed a general cylindrical or blocky morphology with quite abrupt upper and lower limits (abrupt decrease in gamma ray values. The facies show aggrading features within the sand body.
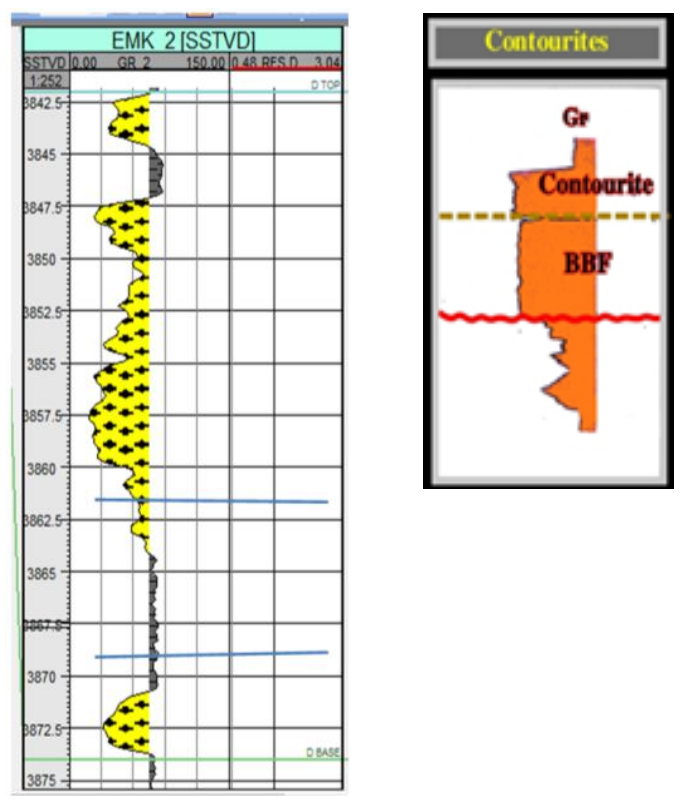

Blocky and serrated shape showed cylindrical feature but without abrupt terminations and facie dipping seaward. Interpretation

This interprets slope fans depositional system. Reference Vail et al. (1991) a stacking of increasing and decreasing thickness with interbedded channelized patterns. fow either prograding, retrograding or aggrading features within the sand body

This interprets the basin floor fan depositional system.
Vail et al. (1991)

This interprets contourite in the basin floor fan depositional system.
Vail et al. (1991) 


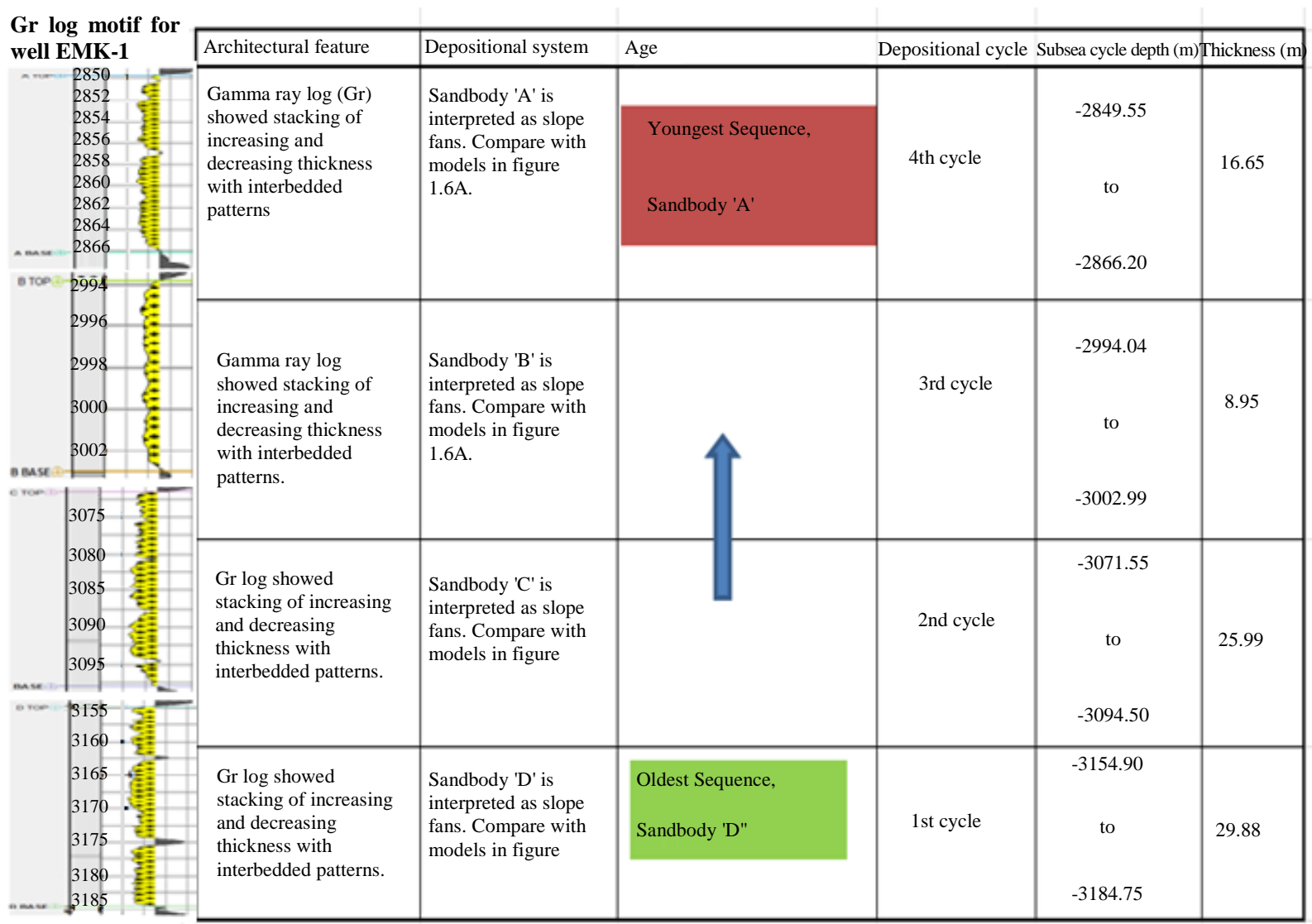

Fig. 6: Interpreted architectural, depositional system, depths/locations and thickness of sand bodies A, B, C and D on well EMK-1 based on gamma ray log

Sand bodies A, B, C and D were used to characterize the internal gross architecture of depositional environment systems of the study area (Fig. 6). The log motifs of prograding, retrograding and aggrading features identified in the study area were used to characterize the depositional environment. The depositional environment is divided into the submarine slope fans and basin floor fans. Based on the identified log motifs, slope fans depositional system, contourite facies in the basin floor fan depositional system and basin floor fan depositional system were identified. Similar log patterns were interpreted in the offshore, Niger Delta and other studies of clastic depositional systems from other basins around the world (Adeogba et al., 2005; Doust and Omatsola, 1990; Weber and Daukoru, 1975; Beka and Otti, 1995).

\section{Conclusion}

The lithofacies and environment of deposition of the EMK field have been described. The study area is within the Akata formation due to the dominant shale interpreted from the gamma ray logs in the study area. Four sand bodies were identified from the gamma ray $\log$. The gamma ray curves and the stacking patterns of the $\log$ s were used to characterize and interpret the depositional environment. This study has further emphasized the importance of the gamma ray logs in lithofacies and depositional environment analysis.

\section{Acknowledgment}

We wish to appreciate the Department of Petroleum Resources (DPR) for approving the released of the data a and Agip Petroleum Development Company for providing the data available

\section{Author's Contributions}

Emeka A. Nwagwu: Obtained the data from the company and did the work as part of his MSc thesis.

Sylvester A. Ugwu: Supervised the thesis.

Godwin O. Emujakporue: Co-supervised the thesis and also prepared the manuscript.

R. Oghonya: Reviewed and typeset the manuscript. 


\section{Ethics}

The article is original and has not been published or sent for review elsewhere.The manuscript was read and approved by the authors and there is no conflict of interest and ethical issues.

\section{References}

Adeogba, A.A., T.R. Mchargue and A. Graham, 2005. Transient Fan architecture and depositional control from near-surface 3D seismic data, Niger Delta Continental Slope. AAPG Bull., 89: 627-643.

DOI: 10.1306/11200404025

Amajor, L.C., 1986. Fluvial fan facies in the Miocene Pliocene coastal plain sands, Niger Delta. Sed. Geol., 29: 1-20.

DOI: $10.1016 / 0037-0738(86) 90013-8$

Avbovbo, A.A., 1978. Tertiary lithostratigraphy of Niger Delta. AAPG Bull., 62: 295-300.

DOI:

10.1306/C1EA482E-16C9-11D7$8645000102 \mathrm{C} 1865 \mathrm{D}$

Beka, F.T. and M.N. Otti, 1995. The Distal Offshore Niger Delta: Frontier Prospects of Mature Petroleum Province. In: Geology of Delta, Oti, M.N. and Postma (Eds.), A.A. Balkema, Rotterdam, pp: 237-241.

Bouma, A.H., 1962. Sedimentology of Some Flysch Deposits: A Graphic Approach to Facies Interpretation. 1st Edn., Elsevier Pub. Co., New York, pp: 168.

Bouma, A.H., W.B. Normak and N.E. Barnes, 1985. Submarine fans and related Turbidite Systems. 1st Edn., Springer, New York, ISBN-10: 0387961429, pp: 351 .

Burke, X., 1972. Longshore drift, submarine canyons and submarine fans in the development of Niger delta. AAPG Bull., 56: 1975-1983.

DOI: $\quad 10.1306 / 819 A 41 A 2-16 C 5-11 D 7-$ $8645000102 \mathrm{C} 1865 \mathrm{D}$

Corredor, F., J.H. Shaw and F. Bilotti, 2005. Structural Styles in the deepwater fold and thrust belt of the Niger Delta. AAPG Bull., 89: 753-780.

DOI: 10.1306/02170504074

Covault, J.A. and S.A. Graham, 2008. Turbidite architecture in proximal foreland basin - system deepwater depocenters, insights from the Cenozoic of Western Europe. Austr. J. Earth Sci., 101: 36-51.

Dalrymple, R.W. and K. Choi, 2007. Morphologic and facies trends through the fluvial marine transition in tide-dominated depositional systems: A schematic framework for environmental and sequenceStratigraphic interpretation. Earth Sci. Rev., 81: 135-174. DOI: 10.1016/j.earscirev.2006.10.002
Doust, H. and E.M. Omatsola, 1990. Niger delta divergent and passive margin basins. AAPG Memoir, 48: 201-238.

Emujakporue, G.O., 2017. Petrophysical properties distribution modeling of an onshore field, Niger Delta, Nigeria. Am. J. Geosci., 7: 14-24. DOI: 10.3844/ajgsp.2017.14.24

Evamy, D.D., J.A. Kammserling, W.A. Knaap, F.A. Molloy and P.H. Rowlands, 1978. Hydrocarbon habit of the tertiary Niger Delta. Am. Assoc. Petrol. Geol., 62: 1-39.

Lowe, D.R., 1982. Sediment gravity flows, depositional models with special reference to the deposits of high-density turbidity currents. J. Sedimentary Petrol., 52: 279-297. DOI: 10.1306/212F7F312B24-11D7-8648000102C1865D

Mutti, E. and W.R. Normark, 1991. An Integrated Approach to the Study of Turbidite Systems. In: Seismic Facies and Sedimentary Processes of submarine fans and Turbidite Systems, Weimer, P. and M.I. Link (Eds.), Springer, New York, pp: 75-106.

Readings, H.G. and M. Richards, 1994. Turbidite systems in deep-water basin margins classified by Grain size and feeder system. AAPG Bull., 78: $792-822$.

Rider, M. 2002. The Geological Interpretation of well Logs. 2nd Edn., Rider-French Consulting, Sotland.

Short, K.C. and A.J. Stauble, 1967. Outline of geology of Niger Delta. Am. Assoc. Petrol. Geol. Bull., 51: 761-779. DOI: 10.1306/5D25C0CF-16C1-11D7$8645000102 \mathrm{C} 1865 \mathrm{D}$

Siemers, C.T. and R.W. Tillman, 1981. Recommendations for the Proper Handling of Cores and Sedimentological Analysis of Core Sequences. In: Deep-Water Clastic Sediments, Siemers, C.T., R.W. Tillman and C.R. Williamson, (Eds.), SEPM, pp: 20-44.

Vail, P., 1987. Seismic Stratigraphy Interpretation Using Sequence Stratigraphy; Part 1, Seismic Stratigraphy Interpretation Procedure. In: Atlas of Seismic Stratigraphy, Bally, A.W. (Ed.), AAPG Studies in Geology, pp: 1-10.

Weber, K.J. and E. Daukoru, 1975. Petroleum geology of the Niger Delta. Proceedings of the 9th World Petroleum Congress, (WPC' 75), Tokyo, pp: 202-221.

Weimer, P. and H.S. Pettinghill, 2007. Global overview of deepwater exploration and production, global atlas of deepwater outcrops. AAPG Stud. Geol., 56: 7-11. 